Tohoku J. exp. Med., 1968, 96, 313-317

\title{
Influence of Aminopterin Administration to Dams upon Single Carbon Transfer into Purines of Fetal Brains*
}

\author{
Yoshiro Wada and Tsuneo Arakawa \\ Department of Pediatrics (Prof. Ts. Arakawa), \\ Faculty of Medicine, Tohoku University, Sendai
}

\begin{abstract}
The ${ }^{14} \mathrm{C}$ incorporation into purine bases of fetal brains was investigated when bL-serine-3-1 ${ }^{14} \mathrm{C}$, L-histidine- $2{ }^{14} \mathrm{C}$, or formate $-{ }^{14} \mathrm{C}$ was injected intraperitoneally to dams with or without pre-treatment with aminopterin. The radioactivity of ${ }^{14} \mathrm{C}$ in fetal brain tissues was estimated on the 18 th day of gestation. On the llth day of gestation, DL-serine-3-14 $\mathrm{C}$, L-histidine-2. ${ }^{14} \mathrm{C}$, or formate- ${ }^{14} \mathrm{C}$ was injected to dams intraperitoneally. In the case of aminopterin treatment, aminopterin, $0.076 \mathrm{mg} / \mathrm{kg}$, was injected intraperitoneally to dams on the $10 \mathrm{th}$ day of gestation.

The results in these experimental conditions showed that the ${ }^{14} \mathrm{C}$ incorporation from formate $-{ }^{14} \mathrm{C}$ into adenine of fetal brains and that from DL-serine $-3^{-14} \mathrm{C}$ into guanine of fetal brains were impaired significantly by aminopterin injection to dams prior to injections of the labeled materials.
\end{abstract}

Mental retardation, brain atrophy and dilatation of cerebral ventricles were found commonly in both the formiminotransferase deficiency and $\mathrm{N}^{5}$ methyltetrahydrofolate transferase deficiency syndromes., ${ }^{12}$ We are of the opinion that the brain atrophy and ventricular dilatation observed in these syndromes may result from an impaired purine biosynthesis of the brain in the fetal life due to a functional deficiency of folate. ${ }^{1,2}$

Our conception mentioned above seemed to be supported by an experimental production $^{3}$ of brain atrophy associated with ventricular dilatation without any other gross malformations in rat offsprings when dams were given 6-mercaptopurine, $20 \mathrm{mg} / \mathrm{kg}$, intraperitoneally on the $11 \mathrm{th}$ day of gestation.

In the present study the ${ }^{14} \mathrm{C}$ incorporation into fetal brain purines is examined when dams are given on the 11th day of gestation an intraperitoneal dose of DLserine-3-1 ${ }^{14} \mathrm{C}$, L-histidine-2- ${ }^{14} \mathrm{C}$, or formate $-{ }^{14} \mathrm{C}$, and it is estimated comparatively when dams are injected with aminopterin on the 10th day of gestation, just prior to the day when the labeled materials are given.

Received for publication, July 4, 1968.

* Supported in part by a grant of National Institute of Child Health and Human Development, HD-01505-04, U.S.A. 


\section{Methods and Materials}

Female rats of the Wistar strain were used and maintained on a standard diet purchased from the Oriental Co. Tokyo, Japan.

The onset of pregnancy was determined by examining the vaginal content of sperm, and the morming of massive sperm findings in the vagina was regarded as day zero of gestation.

Fetalized animals were divided into two groups (Groups A and B): Group A consisted of 19 rats and served as the control group; Group B consisted of 9 rats and all the rats of this group were given an intraperitoneal dose of aminopterin, $0.076 \mathrm{mg} / \mathrm{kg}$, on the 10th day of gestation.

On the 11th day of gestation, rats of Group A were divided into three subgroups (Subgroups $A \cdot a, A \cdot b$ and $A-c$ ); and those of Group $B$ were also divided into three subgroups (Subgroups B-a, B-b and B-c), and labeled materials were injected in the following way: To each of rats of Subgroups A-a and B-a, $25 \mu \mathrm{c}$ of DL-serine-3 ${ }^{14} \mathrm{C}$ (specifie activity of $38.9 \mathrm{mc} / \mathrm{mM}$ ) were injected intraperitoneally. To each of rats of Subgroups A-b and B-b, 25 $\mu \mathrm{c}$ of L-histidine-2 ${ }^{14} \mathrm{C}$ (specific activity of $41.5 \mathrm{mc} / \mathrm{mM}$ ) were given intraperitoneally. And to each of rats of Subgroups $\mathrm{A}-\mathrm{e}$ and $\mathrm{B}-\mathrm{c}, 25 \mu \mathrm{c}$ of sodium formate ${ }^{14} \mathrm{C}$ (specific activity of $4.01 \mathrm{mc} / \mathrm{mM}$ ) were injected intraperitoneally.

On the eighteenth day of pregnancy all the dams were decapitated and fetuses were removed from the placenta. The brains from fetuses of one and the same dam were collected and weighed, then subjected to the extraction procedure of nucleic acids from brain tissues, followed by an estimation of the radioactivity of ${ }^{14} \mathrm{C}$ incorporated into fetal brain purine bases.

Extraction of acid soluble fractions and nucleic acids from brain tissues was carried out according to Schneider et al.'s method. ${ }^{4, \overline{0}}$ Brain tissues, 0.3-1.5 g, were homogenized by a Potter's blender with approximately $8 \mathrm{ml}$ of $0.5 \mathrm{~N}$ perchloric acid, and the final volume of the homogenates was made up to $10.0 \mathrm{ml}$ with an addition of $0.5 \mathrm{~N}$ perchloric acid. The homogenates were kept at $95^{\circ} \mathrm{C}$ for 15 minutes, ${ }^{6}$ then centrifuged. The deposits were again subjected to the extraction procedure in the same way as described above. The supernatants were combined together and added with $1.0 \mathrm{ml}$ of $1 \mathrm{~N}$ silver nitrate solution. The mixture was left to stand overnight, and then centrifuged. To the precipitate $20 \mathrm{ml}$ of $1 \mathrm{~N}$ hydrochloric acid were added and the mixture was kept in boiling water bath for 60 minutes. After completion of hydrolysis, the hydrolysate was placed on a Dowex $50 \times 8\left(\mathrm{H}^{+}\right)$column $^{2}(1 \times 10 \mathrm{~cm})$. After washing the column with $60 \mathrm{ml}$ of deionized water, purine bases were washed out from the column with $60 \mathrm{ml}$ of $0.5 \mathrm{~N}$ ammonium hydroxide. All the eluate was dried up on a steam bath, and the residue was dissolved in a small amount of $0.5 \mathrm{~N}$ ammonium hydroxide.

The resulting ammonium hydroxide solution was subjected to one dimensional paper chromatography of purine bases using the Toyo-filter paper No. 50 and a solvent ${ }^{\mathrm{B}}$ consisting of n-butanol: acetic acid: water $(2: 1: 1, \mathrm{v} / \mathrm{v})$.

The radioactivity of ${ }^{14} \mathrm{C}$ in spots corresponding to those of adenine and guanine was measured by an automatic radioisotope scanner.

\section{Results and Discussion}

The averages of the radioactivity of ${ }^{14} \mathrm{C}$ incorporated into fetal brain purine bases from DL-serine- $3-{ }^{14} \mathrm{C}$, which had been given intraperitoneally to dams on the 11th day of pregnancy, were shown in Fig. 1, indicating that they were lower in Group B (fetuses from dams with aminopterin injection) than in Group A (fetuses from dams without aminopterin injection). On a statistical examination a significant difference was found only in the radioactivity of ${ }^{14} \mathrm{C}$ incorporated into guanine fraction between Groups A and B (cf. Tables 1 and 2). 


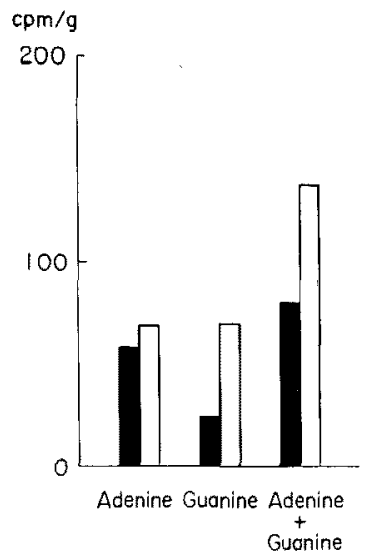

Fig. 1. The averages of the ${ }^{19} \mathrm{C}$-incorporation into adenine and guanine of fetal brains from DL-serine-3.14C injected intraperitoneally to dams on the 11 th day of gestation. Black columns were values obtained from fetuses of dams to which aminopterin injection was done on the loth day of gestation (Group B), and white columns from dams without aminopterin injection (Group A).

TARLE 1. Incorporation of ${ }^{14} \mathrm{C}$ into purine bases of fetal brains from serine-3-14C, histidine-2. ${ }^{14} \mathrm{C}$, and formate $-{ }^{14} \mathrm{C}$ injected intraperitoneally into dams on the 11th day of pregnancy

\begin{tabular}{|c|c|c|c|c|c|c|}
\hline \multirow[t]{2}{*}{ Group A } & \multirow{2}{*}{$\begin{array}{r}\text { No. of } \\
\text { dams }\end{array}$} & \multirow{2}{*}{$\begin{array}{l}\text { Fetuses } \\
\text { in } \\
\text { number }\end{array}$} & \multirow{2}{*}{$\begin{array}{l}\text { Total wet weight, } \\
\text { g, of fetal brains } \\
\text { gathered from the } \\
\text { same dam }\end{array}$} & \multicolumn{3}{|c|}{$\begin{array}{l}{ }^{14} \mathrm{C} \text { of purine bases of } \\
\text { fetal brains (cpm/g) }\end{array}$} \\
\hline & & & & Adenine & Guanine & Total \\
\hline $\begin{array}{l}\text { Subgroup A-a } \\
\text { (serine- } 3-{ }^{14} \mathrm{C} \text { ) }\end{array}$ & $\begin{array}{c}1 \\
2 \\
3 \\
4 \\
5 \\
6 \\
7 \\
8 \\
\text { Average }\end{array}$ & $\begin{array}{r}10 \\
8 \\
9 \\
6 \\
11 \\
10 \\
9 \\
9\end{array}$ & $\begin{array}{l}0.9650 \\
0.7330 \\
0.8385 \\
0.4680 \\
1.1055 \\
0.9400 \\
0.7085 \\
0.7745\end{array}$ & $\begin{array}{r}77 \\
48 \\
54 \\
47 \\
87 \\
33 \\
112 \\
90 \\
69\end{array}$ & $\begin{array}{r}58 \\
48 \\
33 \\
60 \\
63 \\
47 \\
137 \\
117 \\
70\end{array}$ & $\begin{array}{r}133 \\
96 \\
87 \\
107 \\
150 \\
80 \\
249 \\
207 \\
138\end{array}$ \\
\hline $\begin{array}{l}\text { Subgroup A-b } \\
\text { (histidine-2.14} \mathrm{C} \text { ) }\end{array}$ & $\begin{array}{c}9 \\
10 \\
11 \\
12 \\
13 \\
14 \\
15 \\
\text { Average }\end{array}$ & $\begin{array}{r}7 \\
10 \\
5 \\
8 \\
10 \\
7 \\
3\end{array}$ & $\begin{array}{l}0.4765 \\
0.9120 \\
0.5490 \\
1.0705 \\
0.8830 \\
0.3880\end{array}$ & $\begin{array}{l}151 \\
200 \\
204 \\
288 \\
220 \\
172 \\
152 \\
198\end{array}$ & $\begin{array}{r}104 \\
44 \\
77 \\
90 \\
85 \\
27 \\
111 \\
76\end{array}$ & $\begin{array}{l}254 \\
244 \\
281 \\
378 \\
305 \\
199 \\
263 \\
274\end{array}$ \\
\hline $\begin{array}{l}\text { Subgroup A-c } \\
\left.\text { (formate }{ }^{14} \mathrm{C}\right)\end{array}$ & $\begin{array}{c}16 \\
17 \\
18 \\
19 \\
\text { Average }\end{array}$ & $\begin{array}{r}11 \\
11 \\
11 \\
8\end{array}$ & $\begin{array}{l}1.1200 \\
0.9620 \\
1.0960 \\
0.8650\end{array}$ & $\begin{array}{l}154 \\
716 \\
202 \\
217 \\
322\end{array}$ & $\begin{array}{l}57 \\
53 \\
39 \\
21 \\
43\end{array}$ & $\begin{array}{l}211 \\
769 \\
241 \\
238 \\
368\end{array}$ \\
\hline
\end{tabular}


TABLE 2. Incorporation of ${ }^{14} \mathrm{C}$ into purine bases of fetal brains from serine-3-14C, histidine-2 $2{ }^{14} \mathrm{C}$, and formate ${ }^{14} \mathrm{C}$ injected intraperitoneally to dams on the 11 th day of pregnancy. Aminopterin, $0.076 \mathrm{mg}$ per $\mathrm{kg}$ of body weight, had been injected intraperitoneally to dams on the 10th day of pregnancy

\begin{tabular}{|c|c|c|c|c|c|c|}
\hline \multirow[t]{2}{*}{ Group B } & \multirow{2}{*}{$\begin{array}{c}\text { No. of } \\
\text { dams }\end{array}$} & \multirow{2}{*}{$\begin{array}{c}\text { Fetuses } \\
\text { in } \\
\text { number }\end{array}$} & \multirow{2}{*}{$\begin{array}{l}\text { Total wet weight, } \\
\text { g, of fetal brains } \\
\text { gathered from the } \\
\text { same dam }\end{array}$} & \multicolumn{3}{|c|}{$\begin{array}{l}{ }^{14} \mathrm{C} \text { of purine bases of } \\
\text { fetal brains }(\mathrm{cpm} / \mathrm{g})\end{array}$} \\
\hline & & & & Adenine & Guanine & Total \\
\hline $\begin{array}{l}\text { Subgroup B-a } \\
\quad \text { (serine-3.14} \mathrm{C})\end{array}$ & $\begin{array}{c}20 \\
21 \\
22 \\
\text { Average }\end{array}$ & $\begin{array}{r}9 \\
10 \\
7\end{array}$ & $\begin{array}{l}0.7730 \\
0.9450 \\
0.6200\end{array}$ & $\begin{array}{l}53 \\
60 \\
60 \\
58\end{array}$ & $\begin{array}{l}25 \\
18 \\
26 \\
23\end{array}$ & $\begin{array}{l}78 \\
78 \\
86 \\
80\end{array}$ \\
\hline $\begin{array}{l}\text { Subgroup B-b } \\
\quad \text { (histidine-2- }{ }^{14} \mathrm{C} \text { ) }\end{array}$ & $\begin{array}{c}23 \\
24 \\
25 \\
\text { Average }\end{array}$ & $\begin{array}{r}9 \\
11 \\
13\end{array}$ & $\begin{array}{l}0.8000 \\
1.1875 \\
1.2265\end{array}$ & $\begin{array}{l}329 \\
193 \\
100 \\
207\end{array}$ & $\begin{array}{l}46 \\
31 \\
42 \\
40\end{array}$ & $\begin{array}{l}375 \\
224 \\
142 \\
247\end{array}$ \\
\hline $\begin{array}{l}\text { Subgroup B-c } \\
\text { (formate- }{ }^{-14} \mathrm{C} \text { ) }\end{array}$ & $\begin{array}{c}26 \\
27 \\
28 \\
\text { Average }\end{array}$ & $\begin{array}{r}9 \\
8 \\
13\end{array}$ & $\begin{array}{l}1.0100 \\
0.8510 \\
1.3510\end{array}$ & $\begin{array}{l}48 \\
27 \\
40 \\
38\end{array}$ & $\begin{array}{l}32 \\
13 \\
27 \\
24\end{array}$ & $\begin{array}{l}80 \\
40 \\
67 \\
62\end{array}$ \\
\hline
\end{tabular}

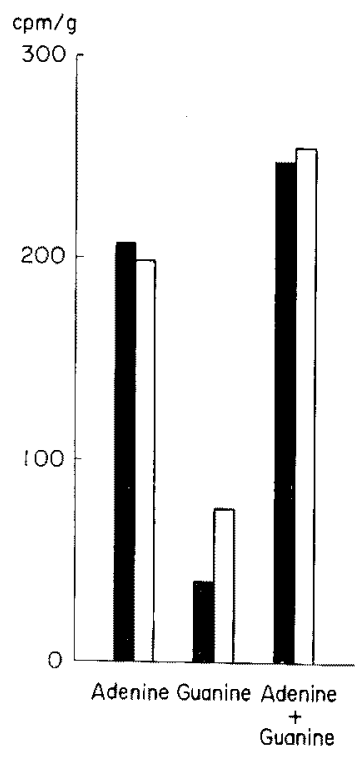

Fig. 2. The averages of the ${ }^{14} \mathrm{C}$ incorporation into adenine and guanine of fetal brains from L-histidine-2-14C injected intraperitoneally to dams on the 11 th day (cf. notes of Fig. 1).

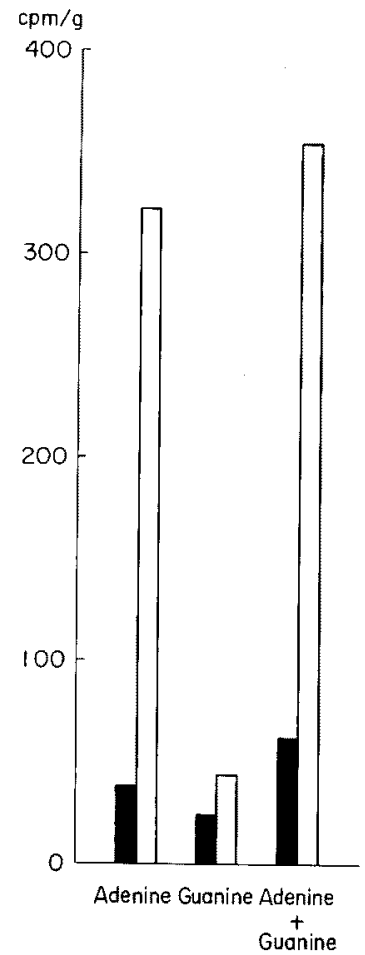

Fig. 3. The averages of the ${ }^{14} \mathrm{C}$-ineorporation into adenine and guanine of fetal brains from ${ }^{14} \mathrm{C}$-formate injected to dams on the 11 th day of gestation (cf. notes of Fig. 1). 
As for the radioactivity of ${ }^{14} \mathrm{C}$ incorporated into purine bases of fetal brains when dams were injected with $\mathrm{L}$-histidine-2 $-14 \mathrm{C}$ on the 11 th day of pregnancy, there was no significant differences between Groups A and B (cf. Fig. 2, and Tables 1 and 2).

In the case of formate- ${ }^{14} \mathrm{C}$ injection to dams on the 11 th day of pregnancy, there were statistically significant differences between Groups A and B in the radioactivity of ${ }^{14} \mathrm{C}$ incorporated into adenine and adenine plus guanine fractions of fetal brains (cf. Fig. 3, Tables 1 and 2).

From the result of the present study, it is likely that the incorporation of single carbons into purine bases of fetal brains was more severely affected when either formate- ${ }^{14} \mathrm{C}$ or $\mathrm{DL}-$ serine $-3-{ }^{14} \mathrm{C}$ was used as the single carbon precursor than when L-histidine-2-14 $\mathrm{C}$ was used, in a condition where the labeled materials were injected on the 11th day of pregnancy to dams to which aminopterin injection was done on the 10th day of pregnancy.

\section{References}

1) Arakawa, Ts., Tamura, T., Higashi, O., Ohara, K., Tanno, K., Honda, Y., Narisawa, K., Konno, T., Wada, Y., Sato, X. \& Mizuno, T. Formiminotransferase deficiency syndrome associated with megaloblastic anemia responsive to pyridoxine or folic acid. Tohoku J.exp. Med., 1968, 94, 3-16.

2) Arakawa, Ts., Narisawa, K., Tanno, K., Ohara, K., Higashi, O., Honda, Y., Tamura, T., Wada, Y., Mizuno, T. \& Hayashi, T. Megaloblastic anemia and mental retardation with hyperfolic acidemia: Probably due to $\mathrm{N}^{5}$-methyltetralaydrofolate transferase deficiency. Tohoku J. exp. Med., 1967, 93, 1-22.

3) Arakawa, Ts., Fujii, M. \& Hayashi, T. Dilatation of cerebral ventricles of rat offspring induced by 6 -mercaptopurine administration to dams. Tohoku. J. exp. Med., 1967, 91, $143-148$.

4) Schneider, W.C. Phosphorus compounds in animal tissues. I. Extraction and estimation of desoxypentose nucleic acid and of pentose nucleic acid. J. biol. Chem., 1945, 161, 293-303.

5) Schneider, W.C., Hogeboom, G.H. \& Ross, H.E. Intracellular distribution of enzymes. VII. The distribution of nucleie acids and adenosinetriphosphatase in normal mouse liver and mouse hepatoma. J. nat. Cancer Inst., 1950, 10, 977-982.

6) Kerr, S.E. \& Seraidarian, K. The separation of purine nucleosides from free purines and the determination of the purines and ribose in these fractions. J. biol. Chem., $1945,159,211-225$.

7) Cohn, W.E. The separation of purine and pyrimidine bases and of nucleotides by ion exchange. Science, 1949, 109, 377-378.

8) Fink, K., Cline, R.E. \& Fink, R.M. Paper chromatography of several classes of compounds: Correlated Rf values in a variety of solvent systems. Anal. Chem., 1963, $35,389-398$. 